\title{
Do Money, Power, Family and Connections Really Matter in Politics? Analysing Factors of Success in the 2010, 2013 and 2016 Philippine Senatorial Elections
}

\author{
JOSEPH ANTHONY L. REYES, BRANDO GABRIEL C. ARCE AND \\ NICOLLE BIEN N. MADRID
}

\begin{abstract}
Myriad debates in electoral politics have drawn attention to the importance of and risks to genuine democracy brought about by factors such as campaign spending, incumbency, political party affiliation and political dynasties. However, only a few studies utilize integrative and multivariate approaches to understanding the contribution of these factors, and this is even rarer for studies on the Philippines of recent times, despite its being among the first and most vibrant democracies in Asia. Examining the relationships to senatorial candidates' total number of votes for the 2010, 2013 and 2016 elections findings reveal overall that total campaign expenditure has a very significant relationship with the number of votes, this being consistent for all of the elections covered by the study. Thus money matters a lot - even when compared with the traditionally highly regarded factors such as incumbency, political dynasty and membership to political parties. This article discusses the results in relation to the socio-political context of the Philippines and provides additional insights and implications of the findings.
\end{abstract}

Keywords: electoral politics, campaign spending, political dynasty, political party, incumbency

\section{Introduction}

Through the years, numerous studies have been conducted to better understand outcomes of state elections, primarily using social-psychological studies. After this approach foundered owing to the instability of political attitudes, it was superseded by the rational voter approach (Matsusaka 1995). However, political analysts and economists found that this still fell short in explaining why campaign spending increases voter turnout and voting behaviour. 
With information being essential for influencing the electorate, the need for campaign resources to enable candidates' public exposure activities becomes apparent. From this, there is the belief that an abundance of resources will lead to a higher number of votes received, since a candidate will be able to disseminate information (Breaux and Gierzynski 1991; Gerber 1998; Johnston and Pattie 2008). However, understanding election outcomes cannot be accomplished by understanding one variable alone. The journey towards understanding election outcomes has been a revolution of ideas, stemming from various perspectives and contexts. In a contemporary context, a clear relationship between campaign expenditure and voting results is present, and this relationship can be explored further once other factors are considered (Eagles 2004; Put et al. 2015). This leads to a question about the significance of campaign spending in relation to election results while there are other substantive variables in place.

\section{Research Objectives}

Various research has engaged in creating models analysing election outcomes. In the process, these studies have generated different models that analyse different combinations of variables, utilizing different samples of observation and at times reaching contrasting results. Although it is considered that research is bounded by its chosen variables, an issue that arises is that each model is limited in its conclusions by the particular data that are used. Specifically, for studies conducted by Gerber (1998), Jacobson (1990) and Abramowitz (1991), the data which were collected are based on the Senatorial and House elections in the USA. In addition, insights derived from the studies of Feinstein (2010) and Clubok, Wilensky and Berghorn (1969) are also derived from analysing information gained from the US Congress. This would mean that the models and findings extracted are primarily focused on testing data from the USA.

The entire scenario may be completely different when contextualizing elections in the Philippines, since traditional politicians view and gauge many of their decisions based on an important yardstick: 'winnability'. Valdehuesa defines the concept of winnability in the Philippines political context as something that 'has less to do with competence or character as with name-recall, wealth, popularity, or connections' (2014: 1). The insights reveal a reality of the voting culture in the Philippines that is different from countries in the West. Therefore, findings from researchers who have drawn conclusions about elections in the West may contradict the situation in the Philippines. 
In light of these insights, this study intends to specifically address the following research queries in the context of Philippine senatorial elections: (1) Is there a relationship between total campaign expenditures and total number of votes received by a candidate? (2) Is there a relationship between the incumbency of a candidate and the total number of votes received? (3) Is there a relationship between the membership of a candidate in a political dynasty and the total number of votes received? (4) Is there a relationship between the membership of a candidate in a political party and the total number of votes received?

\section{Significance of the Study}

Quantitative approaches seldom applied in the Philippine context will be used to analyse how the predictive variables relate to the dependent variables in the country. As the study affirms the relationship of the independent variables with gaining votes, the actions of aspiring public servants may be influenced in the future. The findings may also contribute to future models related to understanding election outcomes. By verifying the relationship of the aforementioned variables, this study will allow future researchers to create models around these findings, leading to more informed conclusions.

Given the research objective, a primary implication could be how individuals aspiring to public office would approach the process of achieving electoral victory in the Philippines. Moreover, the findings that will be derived from this study in a Philippines context can contribute to the discussion of other completed literature across the globe. This study could also analyse the very character of a state's electorate, and indicate which variables are significant for electoral victory.

\section{Scope and Limitations}

The analysis focuses on four variables that affect votes received. This study will be bounded in the context of Philippine elections, specifically, the 2010, 2013 and 2016 senatorial elections. Given that the political investigation will be limited to three senatorial election years, all conclusions are limited to the data acquired from the specific years. As a whole, the limitation to a specific number of elections for a particular position in one country signals reservations when it comes to generalizing the effects of the variables that are shown in this study. 


\section{Definition of Terms}

Campaign expenditure refers to the funds spent by a candidate during the election period, regardless of their source. Incumbency is defined as the holding of political office, and incumbents in this study are identified as those holding office prior to the year of senatorial elections. Political dynasty affiliation refers to attachment or connection to a succession of rulers from the same family or group. In this study, political dynasty affiliation is based on whether the candidate has a family member who holds an elected public position in the specific election year. Political party membership is defined as being a member of a formal group of individuals that fields candidates at elections and aspires to hold positions in public office. For this study, political party membership is a formal connection that is identified by the registration of a candidate with a certain political party during the election year.

\section{Review of Related Literature}

\section{Campaign Expenditure}

As a determinant of election outcomes, campaign expenditure has been researched by various scholars for many years in order to understand its effect and extent. It is crucial to understand its degree of influence towards the choices that members of the electorate will make (Breaux and Gierzynski 1991; Gerber 1998; Zhirnov 2016).

For instance, the model made by Benoit and Marsh (2003) estimates the effects of expenditures on individual electoral outcomes in the 1991 Irish elections by testing the coefficients of spending and the coefficient for the interaction of spending and incumbency. Results show that spending is significant in both statistical and substantive terms, and that spending and incumbency interaction is not statistically significant. The researchers find that more spending of candidates in the local elections helped to mobilize voters.

Following this 2003 investigation, Benoit and Marsh (2008) offer an update for the 2002 Irish general elections, providing information about how spending may be different for incumbents and challengers. What is certain from their findings is that an incumbent has a specific advantage in terms of gathering and spending resources. Similar to the previous study, Johnston and Pattie (2008) investigate the same matters, focusing on the impact of campaign spending in the 1997 and 2005 British general 
elections. They conclude that money matters in British general elections and that the average cost of votes are the same for the years investigated (taking inflation into consideration). Furthermore, Pattie, Johnston and Fieldhouse (1995) examine patterns of local party spending on constituencies in Great Britain, and the impacts of this spending on the election results. They conclude that spending is significant for parties and that challengers' spending is more beneficial than incumbents' spending.

Eagles (2004) studies the effects of election local spending for candidates of each major party in the 1993 and 1997 federal elections in Canada. The study concludes that local spending is effective in gaining party votes and recognizes that campaign spending has a clear impact, despite varied effects amongst parties and elections. Analysis by Put, Maddens and Smulders (2015) of the effects of campaign spending of candidates in the Belgian local elections finds that candidates who spend more per registered voter obtain more preferential votes. However, they also declare that the result of their study should not be overstated because of different factors to be considered in a local election, such as incumbency.

Breaux and Gierzynski (1991) analyse the level of spending if it is associated or correlated with an increase in primary vote. They conclude that expenditure is significant for state legislative primary outcomes. Moreover, Pinto-Duschinsky (2002) tackles political finance on a global scale, also questioning the growing cost of advertising. It is found that campaign expenditure has continued to rise in the decade before the study and further that there is not enough evidence to gain a view regarding the rise in campaigning costs for their potential to be a major cause of corruption.

\section{Election Outcomes:}

\section{Incumbent Spending vs Challenger Spending}

Theoretically, incumbent spending would be more effective than comparable challenger spending. This theoretical claim is based on incumbents' possession of organizations and expertise, which makes their expenditure more efficient (Gerber 1998). Moreover, Gerber (1998) explains that this would mean the marginal effects of challenger spending would be lower when compared with incumbent spending. On the contrary, Gary Jacobson (1990) explains that incumbents already have advantages; this is why any expenditure is considered a mere addition to existing activity. Moreover, Jacobson emphasizes the fact that incumbents are generally well known, and additional exposure from campaign spending brings 
about little further knowledge. Challengers benefit to a greater extent, since the public initially possess minimal knowledge about them.

Re-examining the traditional view that challenger spending is more effective than that of incumbents by reassessing spending effects with instrumental variables, Gerber (1998) points out that challenger and incumbent spending can be treated endogenously. The effects of 'challenger quality and partisan, ideological, and economic conditions on the incumbent's percentage of the vote' (p. 403) are acknowledged in his study, which incorporates instrumental variables such as challenger wealth, state voting age population and lagged spending.

In Abramowitz's study (1991), a comprehensive comparison of campaign spending during the years 1974,1976, 1984 and 1986 is conducted, and it is discovered that challenger spending declined significantly, by more than 30 per cent. The study further indicates that low-level competition in US House elections meant that there was a significant cost to acquiring seats. As a whole, Abramowitz's study raises the idea that substantial spending during campaigns yields electoral gains and increases campaign competition.

Benoit and Marsh (2003) also analyse the spending effects of incumbent and challenger candidates. Their study concludes that, regardless of the amount spent, it is generally incumbents who have a higher probability of winning. Johnston and Pattie (2008) also assess the relative impact of spending by incumbents and challengers, where they recognize the argument that incumbents have an advantage over challengers. One of the results of their study is that, when political parties spend more than the average cost, challengers benefit more from the additional expenditure than the incumbent.

Erikson and Palfrey (1998) estimate the effects of incumbent spending and challenger spending in the 1970s and 1980s US House elections, considering that incumbents outspend challengers. Their study concludes that incumbency spending advantage is a cumulative process, but varies during a career. However, over time, incumbent spending is less effective than challenger spending. Challengers will face two problems: they may not raise and spend enough money compared with the incumbent and they may not be able to contest the incumbent's reputation, which in large part is built on past spending.

\section{Political Dynasties}

Occupational following is one primary resource that helps us to understand the substantial existence of second-generation politicians. This 
occurs at high rates when the success of the profession is dependent on capital and goodwill (Feinstein 2010). Blau and Duncan (1967) explain that gaining such occupation-specific capital and goodwill is more accessible for second-generation individuals, giving them an advantage. Furthermore, Feinstein (2010) elucidates the importance of the connections that first-generation politicians establish with various parties because they aid second-generation politicians. He likens politicians to businessmen, where personal credibility matters and the credibility and popularity of the first generation can be used to the advantage of their successors.

The study by Clubok, Wilensky and Berghorn (1969) involves a search of the Biographical Directory of the American Congress to verify family ties from 1789 to 1960 . Their findings reveal that there has actually been a gradual decrease in family ties in Congress over the years.

Another political inquiry, by Dal Bó, Dal Bó and Snyder (2009), aims to identify the higher rate of occupational following; second-generation individuals whose relatives only served one term, or those second-generation individuals with relatives who held office for multiple terms. The conclusion indicates that there is a higher rate of occupational following for those individuals whose family members served a longer period in office. Similarly, a study by Feinstein (2010) investigates the dynastic advantages in the 1994-2006 US Congress. The study finds that dynastic members are given higher ratings by respondents and argues that this is a result of 'electoral bump' brought about by branding.

\section{Political Parties}

Meadows (1962) describes how the Liberal and Nacionalista political parties in the Philippines picked their candidates and explores the different issues surrounding the conventions of political parties. With these conventions, delegates weigh the winnability of a nominee and his/ her personality. Meadows argues that the 1961 elections dethroned the political machine used by the Nacionalista Party, leading to grassroots strategies by the Liberal Party. Meadows cites the example of Garcia and Macapagal, who each used a different strategy with their respective party. Garcia's winnability was reliant on Nacionalista's party strategy, while Macapagal relied on the Liberal Party attracting people from rural areas. This indicates that one's party initiates ways in which to secure victory.

The investigation of Gibson et al. (2003) looks into political party campaign styles on the web during the 2000 and 2001 presidential and 
general elections in the USA and UK. This study finds that parties make use of web utilities based on primary functions, with the simple motive to communicate. The researchers also acknowledge from their results how parties exercise a communication system that goes top-down, with less desire for two-way communication. This is because 'allowing open chat-rooms or bulletin boards facilities on one's site clearly holds the potential for opening up a tide of damaging abuse' (p. 67).

Also of interest is Kura's (2011) research about how the People's Democratic Party in Nigeria selects candidates, gathers contributions and finances campaigns. It is noted that informal agreements often take place. It is concluded candidate selection and the gathering of contributions may lead to corruption, owing to a lack of transparency, and that a lack of internal democracy and the occurrence of internal crises may lead to powerful oligarchs controlling the party. With these problems, it is also possible to see empirically the form and character of contributions and campaign financing (p. 292).

\section{Conceptual Framework}

Adapted from the approaches in extant literature, the election outcome model that will be tested in this study will include the following variables: the candidate's campaign expenditure, status of incumbency, membership of a political dynasty and membership of a political party. The ability of the model to predict election outcomes using these variables will be tested with the 2010, 2013 and 2016 Philippine senatorial elections. This is to verify the variables' significance in this context, in comparison with the findings relating to Western contexts.

\section{Key Assumptions}

In light of the previous findings that have noted the significance of campaign expenditure by a candidate, this framework will assume that this will most likely have a positive relationship with the votes received by candidates. Second, this model also assumes that, since incumbents are well known to the public, the incumbency variable will act as a significant factor in positively affecting the number of votes received by the aspiring candidate. Furthermore, this model will also include another variable, membership of a political dynasty. Given the insights of previous literature into how second-generation politicians benefit from the network, resources and intangible benefits provided by the first generation, this model assumes that membership of a dynasty will 
allow a candidate to acquire more votes. Lastly, the model takes into account membership of a political party. This final variable assumes a positive relationship between membership and the number of votes received by a candidate, given that political parties can function as tools that increase candidate exposure and platform appeal.

FIGURE 1. Visual representation of variable relationships

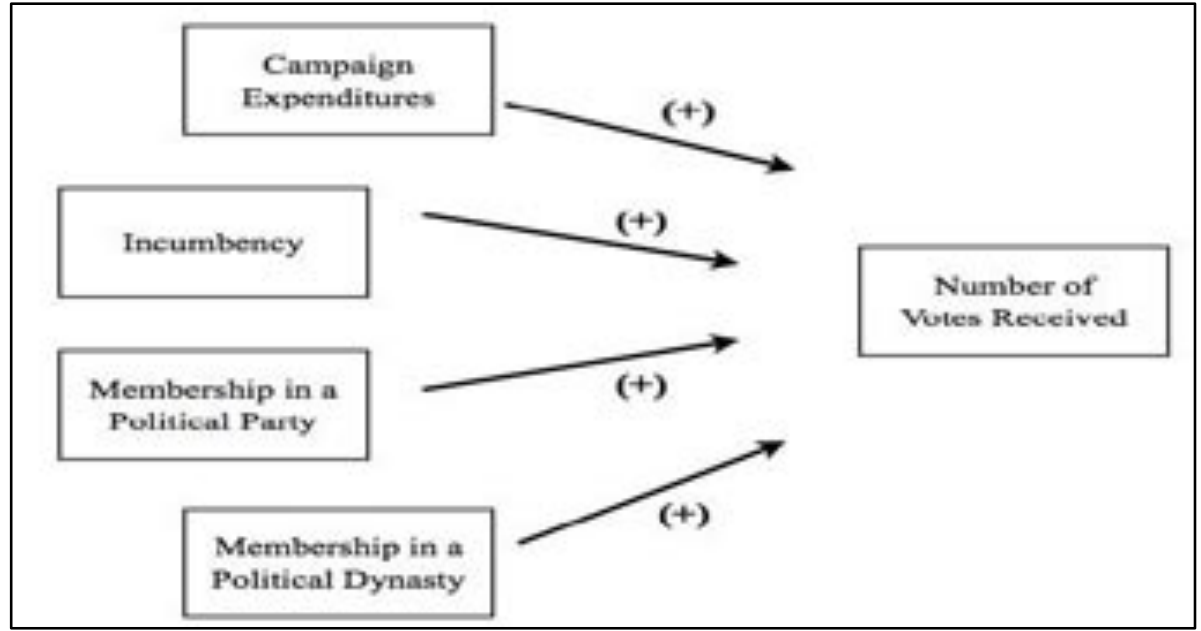

Source: Adapted from the analytical frameworks utilized in literature such as Benoit and Marsh (2003), Eagles (2004) and Johnston and Pattie (2008)

\section{Methodology}

\section{Data}

For this study, a dataset with information about all senatorial candidates in the 2010, 2013 and 2016 Philippine senatorial elections was compiled: total expenditure reported in their Statement of Contributions and Expenditures, incumbency status, membership of a political dynasty and membership of a political party. Each variable of interest was verified based on the specific election in which a candidate took part, using the following: (1) total campaign expenditure of a candidate based on the document that he/she filed with the Commission on Elections during a particular national election year; (2) incumbency verified according to whether or not the candidate was incumbent during a specified election year; (3) membership of a political party verified according to whether or not the candidate was affiliated with a political party during a certain election year; (4) membership of a political dynasty was based on 
whether or not the candidate had relatives (up to the third degree of consanguinity) who were elected to public office.

\section{Collection Procedure}

For total candidate expenditure, the total amount of campaign expenditure of each candidate per election year was obtained from his/her Statement of Contributions and Expenditure that was received from the Commission on Elections. Incumbency was derived from the list of incumbent senators prior to the national elections, which was viewed in the Official Gazette of the Philippines. For membership of a political party, the submitted Statement of Contributions and Expenditures, per election year, was used to verify the political party that the candidate was a member of. Finally, for membership of a political dynasty, the candidate's biographical profile was assessed to observe his/her familial affiliations. After doing this, the list of the Philippine government officials (for the particular year in which a candidate aspired to be senator) was referred to in relation to incumbent relatives.

\section{Analytical Techniques Procedure}

In order to find significant relationships between the variables of interest, data collected was utilized in univariate regression models and also incorporated into a multivariate regression equation for the full model.

\section{Model Equation}

Number of votes received $=a+\beta_{1}($ CSpend $)+\beta_{2}($ Inc $)+\beta_{3}($ PolPar $)+\beta_{4}+($ PolDy $)+\varepsilon$

Where: CSpend is candidate spending; Inc is incumbency; PolPar is membership of a political party; PolDy is membership of a political dynasty; $\varepsilon$ is other factors.

Multivariable equations pave the way for interpreting partial relationships with the presence of other explanatory variables other than one predictive variable; hence, we may thoroughly understand the effect of one variable in association with the others (Agresti and Finlay 2009). In this multivariable equation, a response variable is analysed with the presence of other predictors, as specified by the equation. Taken as a whole, this particular model indicates a positive relationship between all the explanatory variables and the response variable; the increases exhibited by the former will also lead to increases in the latter. 


\section{Results and Interpretation}

The analysis was conducted with the variables of candidates' total campaign expenditure, incumbency, affiliation with a political dynasty and membership of a political party, and their relationship with the total number of votes received. The following sections discuss the results of model testing of these variables for the senatorial election years that were included in the study.

\section{Univariate Linear Regression Results}

As presented in Table 1, using the independent variables of campaign spending, incumbency, political dynasty affiliation and political party membership, univariate linear regression was conducted for the years 2010, 2013 and 2016. Results indicate that membership on its own was not a significant indicator. Campaign spending and incumbency were the most consistent predictors of votes that were received by the candidate in the three election years.

TABLE 1. Univariate regression for each independent variable for 2010, 2013 and 2016

\begin{tabular}{|c|c|c|c|c|c|c|c|c|c|c|c|}
\hline \multicolumn{12}{|c|}{$\begin{array}{c}\text { Linear Regression per Independent Variable } \\
\text { (Number of Votes Received as Dependent Variable) }\end{array}$} \\
\hline & $\begin{array}{l}\text { Elec- } \\
\text { tion } \\
\text { Year }\end{array}$ & Valid N & Mean & Min & Max & SD & Adjusted R & R Square & F Value & df & Sig. F \\
\hline \multirow{3}{*}{$\begin{array}{l}\text { Campaign } \\
\text { Spending }\end{array}$} & 2016 & 42 & 48331789 & 0 & 199146624 & 58048413 & 0.743 & 0.75 & 119.742 & 1 & 0 \\
\hline & 2013 & 33 & 53811708 & 0 & 150401072 & 53341639 & 0.665 & 0.676 & 64.583 & 1 & 0 \\
\hline & 2010 & 51 & 34890428 & 0 & 143084448 & 37167813 & 0.333 & 0.347 & 26 & 1 & 0 \\
\hline \multirow{3}{*}{$\begin{array}{c}\text { Incumbency } \\
(1-\text { Yes, } \\
0 \text { - No })\end{array}$} & 2016 & 42 & 0.0952 & 0 & 1 & 0.2971 & 0.133 & 0.155 & 7.314 & 1 & 0.01 \\
\hline & 2013 & 33 & 0.2121 & 0 & 1 & 0.4151 & 0.239 & 0.263 & 11.048 & 1 & 0.002 \\
\hline & 2010 & 51 & 0.1176 & 0 & 1 & 0.3254 & 0.458 & 0.469 & 43.205 & 1 & 0 \\
\hline \multirow{3}{*}{$\begin{array}{l}\text { Political } \\
\text { Dynasty Af- } \\
\text { fliation } \\
(1-\text { Yes, } \\
0 \text { - No) }\end{array}$} & 2016 & 42 & 0.2381 & 0 & 1 & 0.4311 & 0.106 & 0.128 & 5.864 & 1 & 0.02 \\
\hline & 2013 & 33 & 0.4848 & 0 & 1 & 0.5075 & 0.075 & 0.104 & 3.607 & 1 & 0.067 \\
\hline & 2010 & 51 & 0.2549 & 0 & 1 & 0.4401 & 0.377 & 0.39 & 31.078 & 1 & 0 \\
\hline \multirow{3}{*}{$\begin{array}{l}\text { Political } \\
\text { Party Mem- } \\
\text { bership } \\
(1 \text { - Yes, } \\
0 \text { - No) }\end{array}$} & 2016 & 42 & 0.5952 & 0 & 1 & 0.4968 & 0.04 & 0.064 & 2.713 & 1 & 0.107 \\
\hline & 2013 & 33 & 0.8485 & 0 & 1 & 0.3641 & -0.03 & 0.002 & 0.056 & 1 & 0.814 \\
\hline & 2010 & 51 & 0.8824 & 0 & 1 & 0.3254 & -0.017 & 0.004 & 0.182 & 1 & 0.672 \\
\hline
\end{tabular}

Source: Consolidated dataset by authors 


\section{Campaign Spending}

Linear regression tests established that campaign spending could statistically significantly predict votes received by a senatorial candidate for all three years: $F=26, p<.001$ in 2010; $F=64.58, p<.001$ in 2013; and $F$ $=119.74, \mathrm{p}<.001$ in 2016. Moreover, campaign spending accounted for 33.3 per cent, 66.5 per cent and 74.3 per cent of the explained variability in 2010, 2013 and 2016 respectively.

\section{Incumbency}

Results of linear regression indicated a significant relationship between incumbency and number of votes received for all three years: $F=43.2, p$ $<.001$ in 2010; $\mathrm{F}=11.05, \mathrm{p}=.002$ in 2013; and $\mathrm{F}=43.21, \mathrm{p}=.01$ in 2016. Incumbency accounted for 45.8 per cent, 23.9 per cent and 13.3 per cent of the explained variability in 2010, 2013 and 2016 respectively.

\section{Political Dynasty Affiliation}

The linear regression tests established that political dynasty affiliation could statistically significantly predict votes received by a senatorial candidate in 2010 and 2016, but not in 2013 with $\mathrm{F}=31.08, \mathrm{p}<.001$ in $2010 ; \mathrm{F}=3.61, \mathrm{p}=.067$ in 2013; and $\mathrm{F}=11.05, \mathrm{p}=.02$ in 2016. Affiliation accounted for 37.6 per cent, 7.5 per cent and 10.6 per cent of the explained variability in 2010, 2013 and 2016 respectively.

\section{Political Party Membership}

Results of linear regression for all three election years indicated that there was no significant relationship between political party membership and the number of votes received by senatorial candidates.

\section{Multivariate Regression Results}

This portion of the research allows us to analyse the relationship of the variables of interest with the total number of votes received in a simultaneous manner, using the multiple regression method at 95 per cent confidence level. The models for the three election years are described in Table 2. This article hypothesizes that total campaign expenditure and incumbency have a positive relationship with the total number of votes received: 
$\mathrm{Ho}_{1}$ : There is no linear relationship between the total campaign expenditure and the total number of votes received.

$\mathrm{Ha}_{1}$ : The higher the total campaign expenditure, the higher the number of votes received.

$\mathrm{Ho}_{2}$ : There is no linear relationship between a candidate's incumbency and the total number of votes received.

$\mathrm{Ha}_{2}$ : If a candidate is incumbent, a greater number of votes will be received.

$\mathrm{Ho}_{3}$ : There is no linear relationship between a candidate's political dynasty affiliation and the total number of votes received.

$\mathrm{Ha}_{3}$ : If a candidate is affiliated with a political dynasty, a greater number of votes will be received.

$\mathrm{Ho}_{4}$ : There is no linear relationship between a candidate's membership of a political party and the total number of votes received.

$\mathrm{Ha}_{4}$ : If a candidate is a member of a political party, a greater number of votes will be received.

TABLE 2. Multivariate regression model utilizing all four independent variables

\begin{tabular}{|c|c|c|c|c|}
\hline \multicolumn{4}{|c|}{ Multivariate Regression (Number of Votes as Dependent Variable) } \\
\hline \multirow{3}{*}{$\begin{array}{c}\text { Campaign } \\
\text { Spending }\end{array}$} & $\begin{array}{c}\text { Election } \\
\text { Year }\end{array}$ & Valid N & Coefficient & Standard Error \\
\cline { 2 - 5 } & 2016 & 42 & 0.099 & 0.011 \\
\cline { 2 - 5 } & 2013 & 33 & 0.090 & 0.012 \\
\hline \multirow{3}{*}{$\begin{array}{c}\text { Incumbency } \\
(1 \text { - Yes, 0 - No) }\end{array}$} & 2010 & 51 & 0.053 & 0.015 \\
\cline { 2 - 5 } & 2016 & 42 & 3208421.213 & 1875897.283 \\
\hline \multirow{2}{*}{$\begin{array}{c}\text { Political Dynasty } \\
\text { Affliation } \\
(1-\text { Yes, 0 - No) }\end{array}$} & 2010 & 33 & 5755625.059 & 1373980.173 \\
\cline { 2 - 5 } & 2013 & 42 & -1519808.117 & 1379444.071 \\
\hline \multirow{2}{*}{$\begin{array}{c}\text { Political Party } \\
\text { Membership } \\
(1-\text { Yes, 0 - No) }\end{array}$} & 2010 & 33 & 425064.143 & 1273978.29 \\
\cline { 2 - 5 } & 2013 & 33 & 2732347.554 & 1390151.835 \\
\hline Election Year & Valid N & Adjusted R & R Square & Sig. F \\
\hline 2016 & 42 & 0.756 & 0.78 & 0 \\
\hline 2013 & 33 & 0.774 & 0.802 & 0 \\
\hline 2010 & 51 & 0.642 & 0.671 & 0 \\
\hline
\end{tabular}




\section{The 2010 Philippine Senatorial Elections}

With a p-value of 0.0009 (less than 0.05 ), there is enough evidence to reject the first null hypothesis. The regression coefficient value shows that 1 unit of increase in the score of campaign expenditure will yield a 0.05 unit increase in the number of votes received. The multiple regression results show that there is enough evidence to reject the second null hypothesis, with a p-value of 0.000016 (less than 0.05). As for the third and fourth pair of variables, contrary to the aforementioned results there is not enough evidence to reject the null hypotheses for the two pairs in the 2010 Philippine senatorial elections.

TABLE 3. Comparison of unadjusted and 2016 CPI adjusted average expenditure amounts

\begin{tabular}{|c|c|c|}
\hline \multicolumn{3}{|c|}{ Comparison of Average Election Spending Per Year (In Philipine Peso) } \\
\hline Year & Unadjusted Amount & Adjusted Amount (2016 CPI) \\
\hline 2010 & $34,890,427.74$ & $40,892,962.23$ \\
\hline 2013 & $53,811,707.61$ & $57,827,506.69$ \\
\hline 2016 & $48,331,789.45$ & $48,331,789.45$ \\
\hline
\end{tabular}

As shown in Table 3, the comparison of the 2016 Consumer Price Index (CPI) adjusted amounts (to account for inflation) reveal the changes in average campaign spendings by the aspiring senators through the election years covered here. In comparing 2010 and 2013, it may be seen that there is a significant increase in the total expenditure. Similarly, between 2010 and 2016 there is an increase in average spending, but less than 2013's increase over 2010. While it can be acknowledged that average campaign spending increased following the 2010 elections, changes in average spending following the 2010 elections indicate that there is a fluctuation: a substantial increase during the 2013 elections, followed by a decrease in 2016 .

\section{The 2013 Philippine Senatorial Elections}

With a p-value of 0.0000 (3.79753E-08, less than 0.05), there is enough evidence to reject the first null hypothesis. The regression coefficient value shows that 1 unit of increase in the score of campaign expenditure will yield a 0.089 unit of increase in the number of votes received. Second, a p-value of 0.00025 (less than 0.05 ) indicates rejection of the second null hypothesis. As mentioned, the third and fourth hypotheses, pertaining to the variables on political dynasty and political party membership, have, once again, failed to reject their null hypotheses. 


\section{The 2016 Philippine Senatorial Elections}

From the results, with a p-value of 0.0000 (2.348E-11, less than 0.05$)$, there is enough evidence to reject the first null hypothesis. As for the regression coefficient, 1 unit of increase in the score of campaign expenditure will yield a 0.099 unit of increase in the number of votes received. However, as for the second pair, the p-value of 0.096 (not less than 0.05) indicates a failure to reject the second null hypothesis. Similarly, the variables of political dynasty and political party membership also fail to reject their null hypotheses.

\section{Discussion}

Various literature has linked campaign expenditure with the number of votes received, grounded on the theory that an increase in the former also increases the latter. This theory assumes that increasing campaign expenditure can enable candidates to exhaust all means of reaching out to voters (Breaux and Gierzynski 1991). Multiple scholars have affirmed the significance of campaign expenditure over voting results, namely Benoit and Marsh (2003), Johnston and Pattie (2008), Johnston, Pattie and Fieldhouse (1995), Eagles (2004) and Put, Maddens and Smulders (2015). All their conclusions support this relationship.

Findings of this study utilizing 2010, 2013 and 2016 data for Philippine senatorial elections reveal that campaign expenditure by a candidate had a positive and significant relationship with the number of votes received. The multiple regression results for these three years indicate we should reject the null hypothesis that there is no positive linear relationship between the two. With the indication of the multiple regression model's high predictive capacity, results strongly suggest the significant effect of campaign expenditure on the number of votes received. In relation to the cited literature, it can be surmised that the availability of financial resource and the capacity to spend it are truly critical factors for election victory in the Philippines.

The collected Statements of Contributions and Expenses of aspiring senatorial candidates show that expenditure revolved around the employment of campaign workforce, the production of campaign paraphernalia, travel expenses and miscellaneous expenses. There is value in knowing the particular items that candidates pay for during election season in the Philippines, since these pave the way for better understanding the significance of campaign spending. The need for the goods and services that make up legal expenditure compels candidates 
to have sufficient funds to operationalize their campaign. Checking total expenditure against candidate net worth, it appears that spending goes beyond their personal capacities.

As demonstrated by the data acquired (see Table 4), the majority of the successfully elected senators in the 2013 Philippine national elections previously exceeded their own net worth in their electoral spending. In fact, among the 12 victors, only elected individuals such as Poe-Llamanzares and Villar had expenditure that did not exceed their official net worth. This information highlights the reality that the net worth of candidates may not be enough to cover necessary campaign expenditure.

TABLE 4. Total expenditures vis-à-vis net worth of the elected senatorial candidates, 2013

\begin{tabular}{|c|c|c|c|c|c|c|}
\hline Last Name & First Name & Rank & Votes & $\begin{array}{c}\text { Total } \\
\text { Expenditures }\end{array}$ & Net Worth & $\begin{array}{c}\text { Surplus / } \\
\text { Deficit }\end{array}$ \\
\hline $\begin{array}{c}\text { POE } \\
\text { LLAMANZARES }\end{array}$ & Mary Grace & 1 & $20,337,327$ & $129,109,598$ & $147,801,341$ & $18,691,743$ \\
\hline LEGARDA & Lorna Regina & 2 & $18,661,196$ & $83,034,205$ & $41,904,809$ & $-41,129,396$ \\
\hline CAYETANO & Alan Peter & 3 & $17,580,813$ & $131,044,782$ & $22,558,333$ & $-108,486,449$ \\
\hline ESCUDERO & Francis Joseph & 4 & $17,502,358$ & $100,723,309$ & $7,965,820$ & $-92,757,489$ \\
\hline BINAY & Maria Lourdes & 5 & $16,812,148$ & $128,695,057$ & $63,935,488$ & $-64,759,569$ \\
\hline ANGARA & Juan Edgardo & 6 & $16,005,564$ & $120,136,753$ & $93,817,582$ & $-26,319,171$ \\
\hline AQUINO & Paolo Benigno & 7 & $15,534,465$ & $124,327,988$ & $18,243,166$ & $-106,084,822$ \\
\hline IV & Aquilino III & 8 & $14,725,114$ & $79,656,069$ & $17,089,225$ & $-62,566,844$ \\
\hline TRILLANES & Antonio IV & 9 & $14,127,722$ & $30,135,015$ & $4,282,000$ & $-25,853,015$ \\
\hline VILLAR & Cynthia & 10 & $13,822,854$ & $133,979,127$ & $1,234,458,940$ & $1,100,479,813$ \\
\hline EJERCITO & Joseph Victor & 11 & $13,684,736$ & $138,207,826$ & $72,101,548$ & $-66,106,278$ \\
\hline HONASAN & Gregorio & 12 & $13,211,424$ & $24,111,849$ & $20,997,540$ & $-3,114,309$ \\
\hline
\end{tabular}

Source: Consolidated data from Philippine Commission on Elections (COMELEC), Statement of Assets, Liabilities and Net worth (SALN) of candidates

Because of the difficulty that independent individuals may face, the value of donors is recognized. Hence there is a need for crowdfunding, a mechanism, according to Lim (as cited in Yoon n.d.), that initiates the 'raising [of] funds from a large number of people or "crowd" typically via the Internet to finance a project' (para. 1). Crowdfunding success can be illustrated by Barack Obama's 2008 campaign (he gained significant resources from the working class), as well as that of 2016's Democratic nominee, Bernie Sanders (Yoon n.d.). Despite the potential success of crowdfunding, there are no clear policies for it in the Philippines. The 
former Philippine Stock Exchange president, Francis Lim, has discussed the similarity of crowdfunding to trading stocks (Dantes 2015). Further, he says: 'since crowdfunding necessarily involves fundraising from the public, our Securities Regulation Code (SRC) requires approval from our Securities and Exchange Commission (SEC)' (Dantes 2015: para. 4). During the fourth quarter of 2016, an interview with SEC chairwoman, Teresita Herbosa, included the fact that the corporate regulator is drafting regulations (Mariano 2016).

On the other hand, Overton (2004) notes that donors providing financial resources to candidates should be scrutinized, as they intend to influence the legislation process. This means that political participation is unequal. Given the results shown here, which deem expenditure to be a significant factor in election results, this issue will grow as a cause for concern in the Philippines. Overton's suggestion of the need for regulative policies on donorship or crowdsourcing from the wealthy is relevant given the poverty rate in the country.

There is supporting literature about how the variable of incumbency affects voting results. Jacobson (1990) points out that incumbents are at an advantage since they are well known. Hence, additional exposure does not bring drastic change to people's knowledge. In his model, the independent variables considered are the respondents' party identification, the president's assessment, the economic trend and the amount of spending (challenger and incumbent). His analysis suggests that challenger spending is more significant. As with Jacobson's model, Gerber's study (1998) also includes incumbency as an independent variable, with others such as spending, challenger quality, economic conditions and state partisanship. Gerber's results agree with Jacobson's, with challenger spending being deemed more effective. The results of the multiple regression tests in this study may pave the way for the investigation of this concept in the Philippines' institutions.

Jacobson and Gerber's studies highlight that spending as a challenger is more significant than spending as an incumbent. On the other hand, this research analysed here reaffirms that being an incumbent is still significant. While previous studies have pointed out that spending matters more to challengers, this study's multiple regression analysis reveals that incumbency still counts. Erikson and Palfrey's study (1988) takes a similar approach, with their investigation of incumbent and challenger spending in the 1970s and 1980s House elections in the USA. Using the full information maximum likelihood (FIML) simultaneous approach, they conclude that incumbency does matter. A valuable 
insight derived from the study explains that the study shows evidence that 'new incumbent spending declines with seniority but accumulates to the incumbent's long-term advantage' (Erikson and Palfrey 1980: 355). Erikson and Palfrey's conclusions on incumbency go hand in hand with the findings of this article. While the model testings are different, the resulting conclusions match.

With the multiple regression results' rejection of the second null hypothesis in the 2010 and 2013 Philippine senatorial elections, there are strong grounds for believing there is a positive and significant relationship between incumbency and votes received. However, reservations must still be considered, given that 2016 did not have the same results as the aforementioned years. While it is true that the results of this study affirm Jacobson and Gerber's insights regarding the advantage that these individuals had, it does not align with their study's conclusion that the significant relationship of amount spent for political campaigns and election results only matters if the candidate is a challenger.

Political dynasty affiliation is also shown by previous literature to have a significant effect in elections. Feinstein (as cited in Yoon n.d.) establishes that there is an intergenerational capital, wherein secondgeneration individuals can benefit from resources and brand name to aid them in the electoral process. Blau and Duncan (1967) explain that the cost of such capital and goodwill is easy for second-generation individuals, giving them a better chance of acquiring public positions. Feinstein's ordinary least squares regression study on the 1994 and 2006 House elections investigates the dynasty and experience difference of candidates, as well as differences in expenditure and a particular district's partisanship index, and how these affect election outcomes. Feinstein's results suggest that dynastic candidates have the edge over non-dynastic candidates. In addition, Chhibber (2009) notes that in state-level parties where the need for experience is belittled, factions exist in the institution and resources are centrally controlled, there is a high possibility that change in leadership will revolve around the same family. The available literature clearly tells us of the reality that secondgeneration individuals follow in the first generation's footsteps, and that circumstances in a particular organization can permit dynasties. However, the results do not pair with the conclusions derived from this study's investigation, since there was not sufficient evidence found to be able to reject the third null hypothesis. These differences in results raise questions: there cannot be an absolute claim on the advantage of dynastic candidates. 
Dal Bó, Dal Bó and Snyder's study (2009) highlighted that secondgeneration individuals whose relatives have served longer in public office have higher rates of occupational following. Focusing on the US Congress, testing using two instrumental variable techniques shows that when legislators hold office for a longer period, it is more likely that their relatives will enter the US Congress as well. On the contrary, the results of this study suggest that dynasty affiliation does not have a positive significant relationship with voting results in Philippine elections. While this result raises questions in light of the ideas presented by the literature on dynasties, it can be inferred that political dynasties in the Philippine context may be more significant at regional or provincial levels, since it is there that specific families hold office for long periods, allowing them to create a brand name.

While it is true that the previous literature highlights how dynasties can affect elections, the results garnered by this study indicate that there is not enough evidence to justify any positive significant relationship of the third variable with the dependent variable. Nevertheless, despite such results, there are still some reservations, since there are existing dynasties in the Philippines who continue to have family members in public office. There are names that have been able to establish networks, create brand names and be recalled by the public. This reveals that the ideas that support the effects of occupational following, which may create political dynasties, can also be seen in those who have been able to create a name for themselves. In the light of this, the voting culture in the Philippines can be better explained as one that is influenced by brands and networks, but not necessarily by dynasty affiliations.

The findings on the fourth variable, political party membership, is similar to that of the third variable, since neither has enough evidence to reject the null hypothesis. While previous literature indicates that parties enable mechanisms that aid the garnering of votes, the results from this study show otherwise. For instance, Meadows (1962) cites different methods such as grass-roots methods and political machinery, as well as certain strategies that, as a whole, are intended to increase a candidate's share of the vote. However, this investigation did not yield statistically significant evidence to support such claims. Findings on how political party membership affects the dependent variable, may still be surmised, with the contentions of Gibson et al. (2003) offering an explanation for how an increase in online opportunities to campaign results in the homogenization of political parties. Recent developments in other Asian countries such as Taiwan are also interesting, as they 
highlight the linkage between the wealth gap and electoral campaigns, indicating a new political economy trend wherein class mobilization has become a driver of party politics as identity mobilization is played down (Zheng 2013). For a country such as the Philippines that subscribes to personality- and identity-based politics, such shifts could have considerable implications.

On the other hand, it can still be pointed out from analyses made using the compiled dataset that candidates such as Inocencio (2010), Tinsay (2010), Gordon (2013) and Delos Reyes (2013) spent on their campaign using the financial resources of their party. In this case, it can be understood that political party membership can still have an indirect but positive impact on the number of votes received by a candidate in terms of financial support. Moreover, as pointed out by Meadows (1962), the methods of the Nacionalista Party were overthrown by the Liberal Party. This process reveals how certain parties can be more effective than others or be present as the protest vote option. Thus, membership of those parties can actually be an advantage.

Worth considering as well is the observation by Kura (2011) that a lack of internal democracy in the political parties of the Philippines may result in weak political organizations, and voters who are more likely to disregard affiliation to political parties when they vote. Moreover, the lack of internal democracy in political parties may also lead to oligarchs gaining control over the political party and utilizing them simply as a political tool without a common ideology.

\section{Conclusion}

Election outcome models guided by relevant theories and previous research allow numerous variables that can be incorporated and tested to explain electoral politics. A candidate's campaign expenditure and incumbency are essential factors that must be considered in order to understand the electoral process. The capacity to spend financial resources in elections allows candidates to better present themselves to the public. While resources are essential, being an incumbent is also a considerable factor, as these individuals are well known and popular. Moreover, membership of political dynasties and parties also provides certain advantages through intangible benefits such as networks, influence and being credited for a brand name or name recall. The analysis that has been carried out in this article provides information about how certain variables of interest exhibit a relationship with the total number 
of votes received by a candidate in the 2010, 2013 and 2016 Philippine senatorial elections. Contextual factors and extant literature have been extensively examined to gain relevant insights about the relationships found within the results.

Findings reveal that campaign expenditure had a significant effect when it came to receiving votes during elections, as the multivariate regression test results were consistent in providing evidence that rejects the null hypothesis for all three election years. The variable of incumbency, on the other hand, was not as consistent. Although it was consistent in depicting a moderately positive relationship with votes received, it was not found to be significant in the multivariate model for 2016. Lastly, the analyses for the last two variables considered are very similar to each other as both account for relatively small explained variability in their univariate models. The multiple regression test results also show that neither has enough evidence for each of their null hypotheses, of having no linear relationship with the number of votes received by a candidate, to be rejected.

Thus, in the national senatorial elections of the Philippines, it can be considered that money matters the most in order to be successful - even when compared with the traditionally highly regarded factors such as incumbency, political dynasty and membership of political parties. Future studies may consider further the interactions among these variables, and in particular how they allow political aspirants to gain access to resources for electoral campaigns.

Joseph Anthony L. Reyes has research interests and recent publications on environmental attitudes, behaviours, discourses, and sociodemographic indicators. He obtained his PhD in Environmental Studies from Tohoku University. He was a Research Fellow in Coastal Communities and Health in South East Asia at the University of Exeter, a Research Specialist for the Foreign Service Institute, and an Associate Professor of Political Science and International Studies at De La Salle University. Email: jalreyes@yahoo.com

Brando Gabriel C. Arce and Nicolle Bien N. Madrid are graduating students of De La Salle University, with research and professional experience in political campaigning, national surveys and business economics. Email: brando_arce@dlsu.edu.ph,nicolle_madrid@dlsu.edu.ph 


\section{REFERENCES}

Abramowitz, Alan I. 1991. 'Incumbency, Campaign Spending, and the Decline of Competition in U.S. House Elections'. Journal of Politics 53 (1): 34-56. https:// doi. org/10.2307/2131719

Agresti, Alan and Barbara Finlay 2009. Statistical Methods for the Social Sciences. Upper Saddle River, NJ: Pearson Prentice Hall.

Bacani, Louis. 2013. 'Comelec Releases Final, Official Vote Tally for Senate Polls'. Philippine Star, 6 May. http:/ / www.philstar.com/election-2013/2013/06/06/950868/ comelec-releases-final-official-vote-tally-senate-polls. Accessed 26 May 2017.

Bangko Sentral ng Pilipinas - Statistics - IIP. N.d. http:/ / www.bsp.gov.ph/statistics/ efs_prices.asp. Accessed 14 May 2017.

Benoit, Kenneth and Michael Marsh 2003. 'Campaign Spending in the Local Government Elections of 1999'. Irish Political Studies 18 (2): 1-22. https:/ / doi.org/10.1080 /1364298042000227622

Benoit, Kenneth and Michael Marsh 2008. 'The Campaign Value of Incumbency: A New Solution to the Puzzle of Less Effective Incumbent Spending'. American Journal of Political Science 52 (4): 874-890. https:/ / doi.org/10.1111/j.1540-5907.2008.00348.x

Blau, Peter and Otis Dudley Duncan 1967. The American Occupational Structure. New York: John Wiley \& Sons.

Dal Bó, Ernesto, Pedro Dal Bó and Jason Snyder 2009. 'Political Dynasties'. Review of Economic Studies 76 (1): 115-142. https:/ / doi.org/10.1111/j.1467-937X.2008.00519.x

Breaux, David A., and Anthony Gierzynski 1991. "'It's Money That Matters": Campaign Expenditures and State Legislative Primaries'. Legislative Studies Quarterly 16 (3): 429-443. https://doi.org/10.2307/440106

Chhibber, Pradeep 2009. 'Dynastic Parties: Organization, Finance and Impact'. Party Politics 19 (2): 277-295. https:/ / doi.org/10.1177/1354068811406995

Clubok, Alfred B., Norman M. Wilensky and Forrest J. Berghorn 1969. 'Family Relationships, Congressional Recruitment, and Political Modernization'. Journal of Politics 31 (1): 1035-1062. https:// doi.org/10.2307/2128357

COMELEC Web Development Team. N.d. Official COMELEC Website: Commission on Elections. COMELEC. http:/ / www.comelec.gov.ph. Accessed 28 May 2017.

Dantes, Angelica J.G. 2015, How Legal Is Crowdfunding in the Philippines? Entrepreneur.com.ph, http://www.entrepreneur.com.ph/startup-tips/how-legal-is-crowdfunding-in-the-philippines. Accessed 21 May 2017.

Eagles, Munroe 2004. 'The Effectiveness of Local Campaign Spending in the 1993 and 1997 Federal Elections in Canada'. Canadian Journal of Political Science / Revue Canadienne de Science Politique 37 (1): 117-136.

Erikson, Robert S. and Thomas R. Palfrey 1998. 'Campaign Spending and Incumbency: An Alternative Simultaneous Equations Approach'. Journal of Politics 60 (2): 355-373. https://doi.org/10.2307/2647913

FactCheck Briefs.pdf. N.d. http://www.ateneo.edu/sites/default/ files FactCheck\%20Briefs.pdf. Accessed 26 May 2017.

Feinstein, Brian D. 2010. 'The Dynasty Advantage: Family Ties in Congressional Elections'. Legislative Studies Quarterly 35 (4): 571-598. https:/ / doi.org/10.3162/03629 8010793322366

Gerber, Alan 1998. 'Estimating the Effect of Campaign Spending on Senate Election Outcomes Using Instrumental Variables'. American Political Science Review 92 (2): 401-411. https://doi.org/10.2307/2585672

Gibson, Rachel K., Michael Margolis, David Resnick and Stephen J. Ward 2003. 'Election Campaigning on the WWW in the USA and UK: A Comparative Analysis'. Party Politics 9 (1): 47-75. https:/ / doi.org/10.1177/135406880391004 
Joseph A.L. Reyes, Brando G.C. Arce and Nicolle B.N. Madrid

Jacobson, Gary C. 1990. 'The Effects of Campaign Spending in House Elections: New Evidence for Old Arguments'. American Journal of Political Science 34 (2): 334-362. https://doi.org/10.2307/2111450

Johnston, Ron and Charles Pattie 2008. 'How Much Does a Vote Cost? Incumbency and the Impact of Campaign Spending at English General Elections'. Journal of Elections, Public Opinion and Parties 18 (2): 129-152. https://doi.org/10.1080/1745 7280801987868

Kura, Sulaiman Y. Balarabe 2011. 'Political Parties and Democracy in Nigeria: Candidate Selection, Campaign and Party Financing in People's Democratic Party'. Journal of Sustainable Development in Africa 13 (6): 268-298.

List of Previous Senators - Senate of the Philippines. N.d. https://www.senate.gov. ph/senators/senlist.asp. Accessed 28 May 2017.

Mariano, Keith Richard 2016. 'Corporate Regulator Readies Safeguards for Online Crowdfunding'. Business World Online. http://www.bworldonline.com/ content. php?section $=$ TopStory\&title $=$ corporate-regulator-readies-safeguards-for-onlinecrowdfunding\&id=134979. Accessed 26 May 2017.

Matsusaka, John. G. 1995. 'Explaining Voter Turnout Patterns: An Information Theory'. Public Choice 84 (1-2): 91-117. https:/ / doi.org/10.1007/BF01047803

Meadows, Martin 1962. 'Philippine Political Parties and the 1961 Election'. Pacific Affairs 35 (3): 261-274. https:// doi.org/10.2307/2753186

Official Tally of Votes for the 2013 Senatorial Race. N.d. Rappler. http:/ / www.rappler. $\mathrm{com} /$ nation/politics/elections-2013/features/rich-media/29126-official-tally-votes2013-senatorial-race. Accessed 26 May, 2017.

Overton, Spencer 2004. 'The Donor Class: Campaign Finance, Democracy, and Participation'. University of Pennsylvania Law Review 153 (1): 73-118. https://doi. org/10.2307/4150622

Pattie, Charles J., Ronald J. Johnston and Edward A. Fieldhouse 1995. 'Winning the Local Vote: The Effectiveness of Constituency Campaign Spending in Great Britain, 1983-1992'. American Political Science Review 89 (4): 969-983. https://doi. org/10.2307/2082521

Philippine Center for Investigative Journalism. N.d. http:/ / moneypolitics.pcij.org/\#/ display/231/. Accessed 2 August 2017.

\#PHVote 2016 Philippine Elections: Official Results. N.d. Rappler. http://ph.rappler. com/elections/2016/results/official. Accessed 26 May 2017.

Pinto-Duschinsky, M. 2002. 'Financing Politics: A Global View'. Journal of Democracy 13 (4): 69-86. https:// doi.org/10.1353/jod.2002.0074

Put, Gert-Jan, Bart Maddens and Jef Smulders 2015. 'Buying Local Votes: The Effect of Individual Campaign Spending Under a Semi-Open PR System in the Belgian Local Elections'. Local Government Studies 41 (1): 137-155. https:/ / doi.org/10.1080 /03003930.2014.904227

Transparency Organization N.d. 2010. Corruption Perceptions Index - Results. https:// www.transparency.org/cpi2010/results. Accessed 26 May 2017.

UP Political Society - Posts. N.d. https://www.facebook.com/up.political.society/photos/a.10153957220613374.1073741974.242541193373/10154096869208374/ ?type=3\&theater. Accessed 26 May 2017.

Valdehuesa, Manny 2014. 'Trapo Mentality and Winnability'. Zamboanga Times, 2 September. http:/ / www.zamboangatimes.ph/opinions/12106-trapo-mentalityand-winnability.html. Accessed 7 May 2017.

Yoon, Anum 2017. Political Crowdfunding: Building a Community Instead of a Campaign. Fintechworld.com. https:// fintechworld.com/2017/02/13/political-crowdfundingbuilding-a-community-instead-of-a-campaign. Accessed 26 May 2017. 
Zheng, Zhenqing 2013. 'Taiwan's Wealth Gap and the Evolution of Electoral Politics after the 2008 Global Financial Crisis'. Asian Survey 53 (5): 825-853. https://doi. org/10.1525/as.2013.53.5.825

Zhirnov, Andrei 2016. 'Limited Information and Coordinated Voting in Multi-party Elections under Plurality Rule: The Role of Campaigns'. Electoral Studies 41 (1): 190-201. https://doi.org/10.1016/j.electstud.2016.01.002 